ISSN 1991- 8690

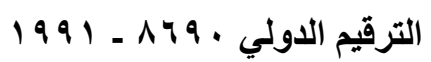

Website: http://jsci.utq.edu.iq

Email: utjsci@utq.edu.iq

\title{
New record of chewing lice Piagetiella titan (Menoponidae: Mallophaga) Isolated from buccal cavity of White Pelican Pelecanus onocrotalus in Thi-Qar province-Southern Iraq
}

\author{
Zainab Abd-Ali Mohammad
}

Bio. Dep.- Coll. of Edu. for Pure Sci.- Thi-Qar Univ.

\section{Summary:}

In the present study the oral cavity of white pelican Pelecanus oncrotalus (collected from Al-Sanaf marsh southern Thi-Qar province, Iraq) was examined in the Biology department / College of Education for Pure Science / Thi-Qar University. A total of 23 chewing lice (10 males and 13 females) were collected from the oral cavity of $P$. oncrotaus bird and identified as Piagetiella titan during microscopial examination. The aim of this study is to give detailed information about $P$. titan, which was first found in Pelicans in Iraq to contribute parasitological fauna of Iraq.

Key words: Piagetiella titan, Pelecanus onocrotalus, buccal cavity, Thi-Qar province, Iraq

$$
\begin{aligned}
& \text { Piagetiella titan (Menoponidae: Mallophaga) تسجيل جديد للقمل القارض } \\
& \text { المززول من التجويف الفمي للبجع الأبيض Pelecanus onocrotalus في محافظة ذي قار، جنوب العرلق } \\
& \text { زينب عبد علي محمد } \\
& \text { قسم علوم الحياة-كلية التربية للعلوم الصرفة-جامعة ذي قار }
\end{aligned}
$$

الخلاصة:

فحص في الدراسة الحالية التجويف الفمي لطيور البجع الأبيض Pelecanus onocrotalus في قسم علوم الحياة/ كلية التربية للعلوم الصرفة/

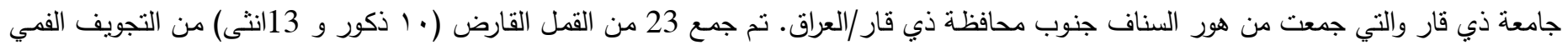

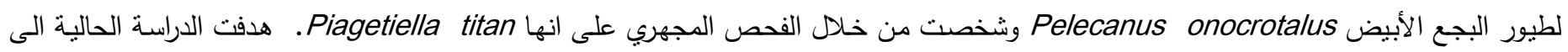
اعطاء معلومات تفصيلية حول P. titan والتي عزلت لاول مرة في العراق ومن طيور البجع. 


\section{Introduction:}

White pelicans Pelecanus onocrotalus are large water birds feeding by hunting fish and living usually in the marine and fresh water. This species and Dalmatian pelican P. crispus are the only species of the family Pelecanidae were reported from Iraq (Allose, 1960). The classification of the aquatic birds was confirmed by Dr. Mehna Kassem Habeeb/ Science College/ Basrah University.The study area Al-Sanaf marsh was located in the western north part of Al-Hammar marsh eastern south of Thi-Qar province. it's area is nearly $250 \mathrm{~km} 2$. It is used by many aquatic birds such as fish eatingbirds. Many of snail and fish species were very common in these areas, it is used as important rural fisheries resources and had a very important ecological effects on man and animal parasites (Mohammad, 2013).The lice living on the bird order Pelecaniformes were found in the genera Pectinopygus, Saemundssonia, Eidmanniella, Fregatiella, Austromenopon, Colpocephalum and Piagetiella (Price et al., 2003).The genus Piagetiella are interesting from an ecological standpoint, since they were principally found in the pouches of the hosts (Price, 1970).Hellenthal et al. (2004) listed chewing lice and their hosts in Belgium and reported P. titan on white pelicans.In France Seguy (1994) mentioned that the P. titan was seen in white pelicans and gave information about its morphological characteristics.Dik and Uslu (2006) recorded P. titan for the first time in Turkey from the buccal cavity of wounded white pelican Pelecanus onocrotalus, they found that the four sternit had a ctenidium in both sides, each second and third tibia had two stout subapical setae, in the female, terminalia had two slender lateral plates and the male genitalia was longer than $3 \mathrm{~mm}$. Tavassoli et al. (2011) isolated $P$. titan from the buccal cavity of white pelican $P$. onocrotalus and they determined the frequency of infestations in white pelicans living in Urmia Lake, Iran.The aim of this study is to give detailed information about P. titan, which was first recorded in Iraq in Pelican birds to contribute parasitological fauna of Iraq.

\section{Materials and Methods:}

The oral cavity of white pelican $P$. oncrotalus (collected from Al-Sanaf marsh southern Thi-Qar province, Iraq) was examined in the Biology department / College of Education for Pure Science / Thi-Qar University.The isolated lice were put into a tube with $70 \%$ alcohol and cleared in lactofenol for a few days. They mounted on microscope slides. These slides were examined through microscope. The specimens were measured in millimeter photographed by using light microscope (Leica, Germany) provided with camera and drew by Camera Lucida (Novel, China).Lice were identified according Price (1970), Dik and Uslu (2006), Tavassoli et al. (2011).

\section{Results:}

A total of 23 lice (10 males and 13 females) were collected from the oral cavity of a white pelican, this lice species caused ulcerative lesions in the walls of oral cavity by their chewing mouth parts. The body of $P$. titan lice was dorso-ventrally flattened and its abdomen was much wider in females than that in males, but less sclerotized (Fig. 1, 2). The head was broad across temples (Fig. 3), the head with deep preocular slit, rounded front, antennae concealed beneath head, maxillary palpus with subterminal setae on last segment and the sclerite of hypopharynx was weakly developed.Occipital setae of female longer than that of female, The venter of each third fumer with 4-5 well developed ctenidia.Thorax with triangular metasternal plates and the abdomen with undivided tergites and without anterior setae, the female tergites separate from pleurites, male with fusion at least on 4-6 segments. Tergal pigmentation of female with 3-6 dark medially and round spiracles, while 1-2 and 7-9 were lighter, in male with 2-5 mostly dark, while 1 and 8-9 were lighter, male with or without evident sterna sclerite on first segment, the venter of each third femur posed five ctenidia (Fig. 4)Female terminalia with slender lateral plates having posterior portion curving medially and the segments 7-8 with fused sternites, anus with greater number of anal setae and the dorsal finger setae more than ventral finger setae (Fig. 5). The structure of ventral female terminalia was the most distinguish feature of this species because it had straight stout lateral plates which much thinner and with posterior end curved medially, while male ventral terminalia 8-9 with fused sternites, male genitalia characterized with large size (Fig. 6), with large genital sac, anterior fourth with very short spinules followed posteriorly by longer spinules reach into posterior half of dense slender spinules.In the present the dimensions of this lice species were done in millimeter, (Table 1), and male and female were and drew by Camera Lucida, (Fig. 7). 
Table. (1). The morphological measurement of P. titan in $\mathrm{mm}$.

\begin{tabular}{||c|c|c|c|c|c|c|c||}
\hline \multirow{2}{*}{ No. } & \multirow{3}{*}{ Character } & \multicolumn{3}{|c|}{ Male } & \multicolumn{3}{c||}{ Female } \\
\cline { 3 - 8 } & Min. & Max. & Av. & Min. & Max. & Av. \\
\hline \hline 1 & Head length & 0.50 & 0.75 & 0.73 & 0.51 & 0.59 & 0.54 \\
\hline 2 & Head width & 1.00 & 1.18 & 1.03 & 1.03 & 1.22 & 1.08 \\
\hline 3 & Prothorax width & 0.77 & 0.88 & 0.79 & 0.78 & 0.89 & 0.81 \\
\hline 4 & Metathorax width & 1.09 & 0.20 & 1.13 & 1.08 & 1.23 & 1.10 \\
\hline 5 & Thorax length & 1.33 & 1.40 & 1.35 & 1.30 & 1.38 & 1.35 \\
\hline 6 & Abdomen length & 3.10 & 4.00 & 3.19 & 3.07 & 4.00 & 3.83 \\
\hline 7 & Total length & 5.00 & 6.12 & 5.41 & 4.93 & 6.14 & 5.53 \\
\hline
\end{tabular}

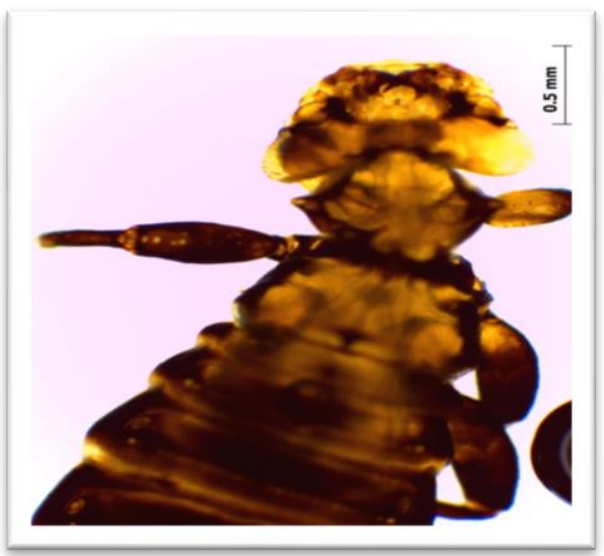

Fig .1: Male

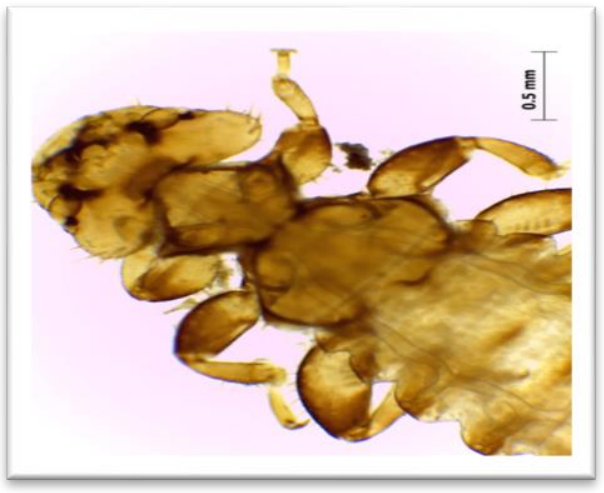

Fig.2: Female

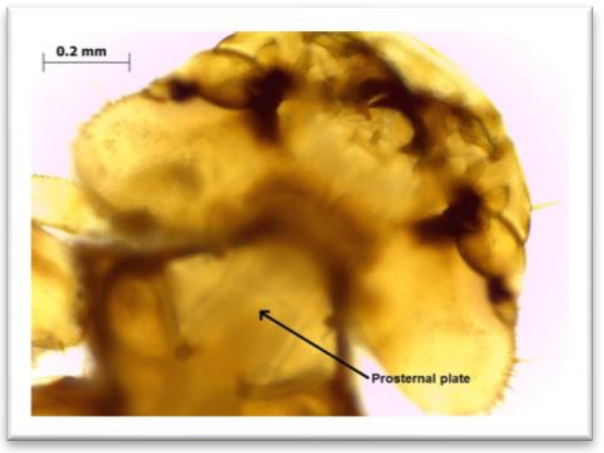

Fig.3: The head

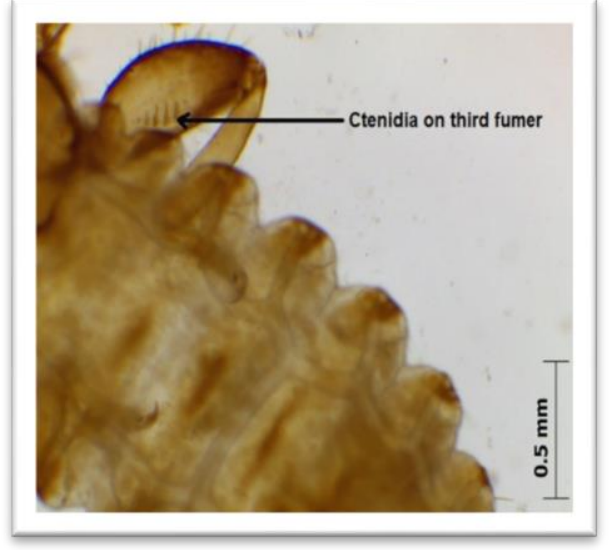

Fig .4: Third fumer

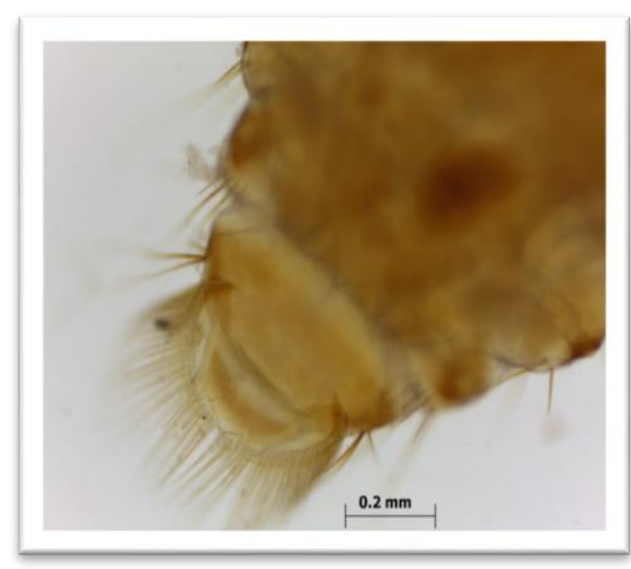

Fig .5: Female posterior end

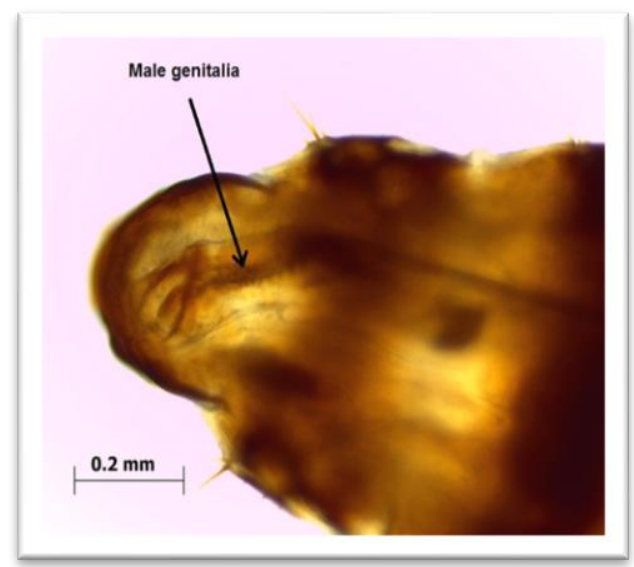

Fig.6: Male posterior end 


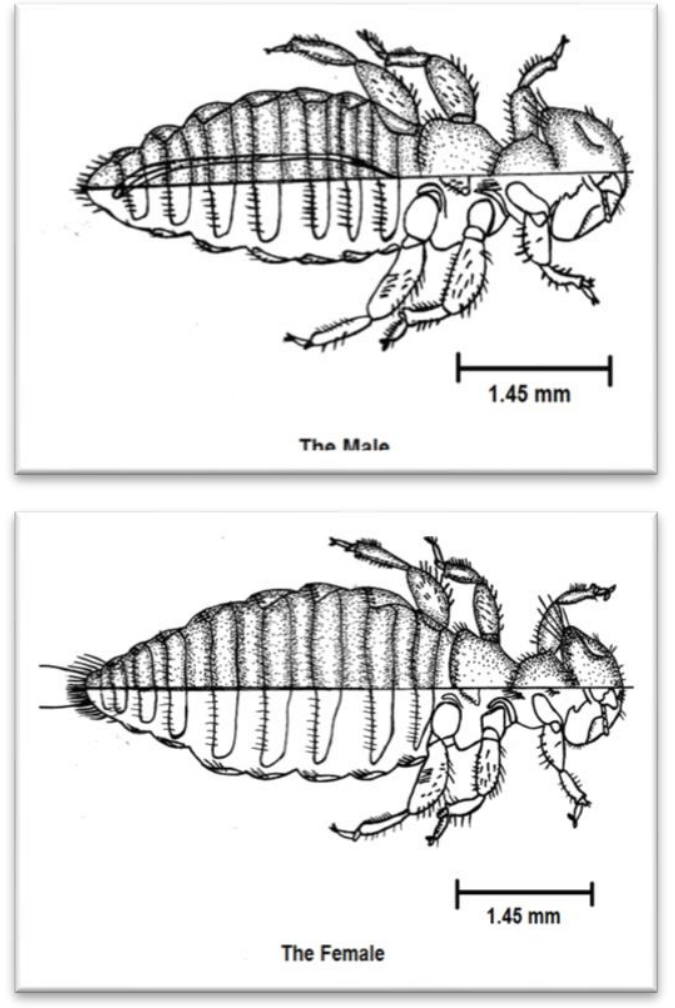

Fig.7: Camera Lucida drawing for male and female of $P$. titan.

\section{Discussion:}

The chewing lice infested pelicans were Pectinopygus forficulatus, Colpocephalum eucarenum and $P$. titan, the third species only was found in oral cavity, while the others on feathers (Dalgleish, 2006).The pelican lice P. titan and its morphological characteristics were described for the first time by Price (1970) and he revealed that these lice were among some of the larger forms, ranging in length from 4 to $6 \mathrm{~mm}$ and with little sexual dimorphism except that associated with generally darker pigmentation and possession of apical tibial processes by the male.According to Price $e t$ al. (2003) the main characteristics of $P$. titan which distinguish it from other species were the both sides of the fourth sternit with a short and well-developed ctenium, the second and third tibia with two stout subapical setae on ventral sides, every stigma with at least one setae, in female the ventral terminalia with slender, curving lateral plates and in male genitalia being longer than $3 \mathrm{~mm}$.Dik and Uslu (2006) found that the second and third tibia had two stout subapical setae, the venter of third femur with 5 ctenidae, but in some specimens, it was observed 6 ctenidae, the female, terminalia had two slender lateral plates and the male genitalia was longer than $3 \mathrm{~mm}$. The current study found that the morphological characteristics were agreed with previous studies as Price (1970), Dik and Uslu (2006) and Tavassoli et al. (2011). According to Price (1970), some dimensions of this species were; Preocular width: 0.85-0.88 mm, temple width: 1.10$1.18 \mathrm{~mm}$, prothorax width: $0.90-0.94 \mathrm{~mm}$, metathorax width: 1.15-1.26 mm, total length: 5.61-6.03 mm. Dik and Uslu (2006) showed some morphological measurements in $P$. titan males: head length $(0.5-0.6)$ $0.57 \mathrm{~mm}$, head width (temple) $(1.13-1.24) 1.17 \mathrm{~mm}$, head index (1.93-2.25) $2.05 \mathrm{~mm}$, prothorax width (0.86-0.91) $0.89 \mathrm{~mm}$, metathorax width (1.13-1.27) $1.20 \mathrm{~mm}$, thorax length (1.38-1.47) $1.42 \mathrm{~mm}$, abdomen length (3.87-4.29) $4.12 \mathrm{~mm}$, total length (5.92-6.28) $6.11 \mathrm{~mm}$, females head length $(0.54-0.61) 0.57 \mathrm{~mm}$, head width (temple) $(1.12-1.27) 1.20 \mathrm{~mm}$, head index (2.07-2.22) $2.12 \mathrm{~mm}$, prothorax width $(0.87-0.91) 0.90$ $\mathrm{mm}$, metathorax width $(1.16-1.26) 1.21 \mathrm{~mm}$, thorax length (1.25-1.41) $1.32 \mathrm{~mm}$, abdomen length (2.794.18) $3.67 \mathrm{~mm}$, total length (4.65-6.42) $5.74 \mathrm{~mm}$. The fact that the adults of $P$. titan chewing lice were located within the pouch and protected from preening, might favor the development of large populations of this lice on pelicans, the heavy populations of lice may exert a serious effect on sick, captive or birds (Tavassoli et al., 2011).In this study the large chewing mouth parts $P$. titan caused some ulcerative lesions in the oral cavity tissues of bird. Tavassoli et al. (2011) reported that the $P$. titan can produce a severe hemorrhagic stomatitis as evidenced in white pelicans. This lesion might cause significant blood loss, and would provide a potential portal of entry for other pathogens.Samuel et al. (1982) reported ulcerative lesions on the body of naked birds approximately 1 week of age and in the throat pouches of older juveniles (2-7 weeks old) of infested pelicans to be due to $P$. peralis.

\section{References:}

Dalgleish, R.C. (2006). Birds and their associated chewing lice.Pelecanidae-Pelicans; http://www.phthiraptera.org/Birds/Pelecanidae.ht $\mathrm{ml}$.

Dik, B. and Uslu, U. (2006). The First Recording of Piagetiella titan (Menoponidae: Mallophaga) on a White Pelican (Pelecanus onocrotalus, Linneaus) in Turkey. Turk. Parasitol. Dergisi J., 30: $128-131$. 
Price, R. D. (1970). The Piagetiella (Mallophaga: Menoponidae) of the Pelecaniformes. Can. Ent. J., 102: 389-404.

Price, R. D.; Hellenthal, R. A.; Palma, R. L. and Johnson, K. P. (2003). Clayton, DH. The Chewing Lice: World Checklist and Biological Overview. Illinois Natural History Survey Special Publication.

Mohammed, K. H. (2013). The environmental impacts of reviving Hor Al-Sanaf by the water of the river of out fall drain in the province of Thi- Qar. Basic Edu. Coll. J. Babylon Univ., 12: 291-311. (In Arabic).

Samuel, W. M.; Williams, E.S. and Blair, A. B. (1982). Infestation of Piagetiella peralis (Menoponidae: Mallophaga) on juvenile white pelicans (Pelecanus onocrotalus, Linneaus).Can. J.Zoo. 60: 951-953.

Seguy, E. (1944). Faune de France. 43. Insectes Ectoparasites (Mallophages, Anoploures, Siphonaptéres). Paris. (English summary).

Tavassoli, M. Salmanzadeh, R. and Jabbari, H. (2011). Infestations of (Menoponidae: Mallophaga) on juvenile white pelicans (Pelecanus oncrotalus L.) in Urmia Lake National Park, northwest Iran. Int. J. Vet. Res., 5: 105-108. 